\title{
The Significance of HLA DRB1*1501 and Oligoclonal Bands in Multiple Sclerosis: Clinical Features and Disability
}

\author{
Renata Balnytè ${ }^{1}$, Daiva Rastenyte் $\dot{1}^{1}$ Ingrida Uloziene் $\dot{e}^{2}$, Dalia Mickevičiené ${ }^{1}$, \\ Erika Skrodeniené $\dot{3}^{3}$, Astra Vitkauskiené ${ }^{3}$ \\ ${ }^{1}$ Department of Neurology, Medical Academy, Lithuanian University of Health Sciences, \\ ${ }^{2}$ Department of Ear, Nose, and Throat Diseases, Medical Academy, Lithuanian University of Health Sciences, \\ ${ }^{3}$ Department of Laboratory Medicine, Medical Academy, Lithuanian University of Health Sciences, Lithuania
}

Key words: multiple sclerosis; human leukocyte antigen DRB1*1501; oligoclonal bands; clinical features; disability.

Summary. The aim of the present study was to determine the value of immunogenetic risk factors and to estimate their relationship with the clinical features and disability status of patients with multiple sclerosis in a Lithuanian population.

Materials and Methods. This was a prospective study of 80 patients with multiple sclerosis. The diagnosis of multiple sclerosis was based on the revised McDonald criteria. Oligoclonal bands $(O C B$ s) of immunoglobulin $G(\operatorname{Ig} G)$ were tested using isoelectric focusing and $\operatorname{Ig} G$ specific immunofixation. HLA DRB1 alleles were genotyped using polymerase chain reaction.

Results. Of all patients, 55\% were positive for OCBs and 56\% for HLA DRB1*1501. OCBpositive patients with multiple sclerosis had higher EDSS scores than their OCB-negative counterparts at onset of the disease (3.93 \pm 1.21 and $3.36 \pm 0.96$ points, respectively; $P=0.02)$ and during the last visit ( $4.31 \pm 2.06$ and $3.09 \pm 1.98$ points, respectively; $P=0.009$ ). The mean relapse rate was higher in the $O C B$-positive group compared with $O C B$-negative group (1.45 \pm 0.69 and $0.58 \pm 0.64$, respectively; $P=0.001)$. OCB-positive patients had higher IgG index compared with $O C B$-negative patients $(P=0.0001)$. No relationship was found between HLA DRB $1 * 1501$ antigen status and the clinical features or EDSS score, and presence or absence of OCB in the present subset of patients with multiple sclerosis.

Conclusions. The presence of oligoclonal bands in the cerebrospinal fluid of the patients with multiple sclerosis was associated with the greater number of exacerbations, higher degree of disability, and higher IgG index. There were no significant associations between the presence of HLA DRB1*1501 allele and the clinical symptoms, course of disease, or disability score.

\section{Introduction}

Multiple sclerosis (MS) is the most common and severe idiopathic demyelinating disease of the central nervous system with etiopathogenesis involving a complex interaction between genetic and environmental factors (1-4). Epidemiological data support a view that MS is caused or triggered by some environmental factors in persons who are genetically susceptible (4). Genes within the human leukocyte antigen (HLA) region account for the largest part of the genetic risk for MS as well as some other immunologically mediated diseases, such as diabetes, seronegative spondyloarthropathies, systemic lupus erythematosus, rheumatoid arthritis, etc. (5).

The strongest association signal comes from HLA-DRB1 in the class II region (4). A great variety of recently reported linkage and genome-wide association studies have established that the most important genetic risk factor in MS is carriage of a single copy of the HLA class II allele DRB1*15 to homozygote forms (6-8). About $60 \%$ of MS patients in Northern Europe are positive for HLA-DRB1*15, compared with $30 \%$ of healthy controls (9).

The HLA complex is not only associated with the disease development, but can also influence certain clinical features and immunological changes in the patients with MS. The interdependence of HLA-DRB1 genotype and phenotypic status of oligoclonal bands has been suggested (6). The higher prevalence of HLA-DRB1*1501 allele may be linked to an earlier onset of the disease, less favorable course, and female gender, the factors which are believed to be particularly important in the prognosis and treatment of MS $(10,11)$.

Oligoclonal bands (OCBs) of immunoglobulin $\mathrm{G}$ $(\operatorname{Ig} G)$ are present in the cerebrospinal fluid (CSF) of the majority $(85 \%-95 \%)$ of clinically definite MS patients and are believed to reflect the intrathecal synthesis of $\operatorname{IgG}$ antibodies $(12,13)$. Detection of the heightened intrathecal IgG synthesis or the pres-

Adresas susirašinėti: R. Balnytė, LSMU MA Neurologijos klinika, Eivenių 2, 50028 Kaunas. El. paštas: rbalnyte@yahoo.com 
ence of OCBs was used in conjunction with clinical evidence to help satisfy the "dissemination in space" requirement of the previous Poser criteria and currently does the same for the revised diagnostic McDonald criteria, when magnetic resonance imaging (MRI) lesions alone do not suffice (14). The prognostic significance of OCBs as well as its association with the HLA-DRB1 genotype has been suggested by some studies but not confirmed by others $(1,6$, 14, 15).

According to the World Health Organization, Lithuania belongs to the region with a high prevalence and incidence of MS (16). There is a lack of investigative studies, establishing the factors influencing disease appearance and its course, estimating the treatment options and prognostic information. To date, no studies have been carried out and no data have been published evaluating immunogenetic status in MS patients of Lithuanian origin. Therefore, the aim of this present study was to determine the value of immunogenetic risk factors and to estimate their relationship with the clinical features and disability status of MS patients in a Lithuanian population.

\section{Material and Methods}

Subjects. The study group comprised the patients with MS, older than 18 years, who were referred to the Department of Neurology at the Hospital of Lithuanian University of Health Sciences in Kaunas during 2009-2010 and who agreed to participate in the study. The study included only patients with confirmed MS diagnosis. MS diagnosis was made according to the widely accepted and revised McDonald criteria (2005) (17). All the laboratory data (OCB status), MRI findings, and data of visual evoked potentials (VEPs) were reviewed retrospectively from the medical records of the patients. Lumbar puncture and cerebrospinal fluid examination was performed at the time of diagnosis. All imaging studies were conducted with a 1.5-T MR scanner (MAGNETOM Avanto, Siemens, Erlangen, Germany) with a standard head coil. The institutional MRI protocol for patients with suspected MS consisted of the following: 1) transverse or sagittal T2-weighted turbo spin-echo sequences (repetition time/echo time/ flip angle, 2.800/13/150); 2) transverse or sagittal T2-FLAIR sequences (9.000/89/2/ TI 2.500); and 3) transverse T1-weighted spin-echo sequences $(608 / 17 / 90)$ before and after administration of gadolinium IV $(10 \mathrm{~mL} / 50 \mathrm{~kg})$. The standard pattern-shift VEPs were recorded for all 80 patients. Registration of VEPs was done by the Evoked Potential Navigating System (Bio-Logic System Corp., USA). The responses were considered abnormal if the P100 latency was longer than 114 ms (i.e., 2 SD above the mean) (18).
Demographic (age at onset of the first symptoms, gender) and clinical data (disease course, duration of the symptoms, disability status) and the findings of all paraclinical tests were collected for all patients. Disability was measured using the Kurtzke Expanded Disability Status Scale (EDSS). The patients were followed up prospectively, and their clinical status was checked every three months.

OCB Testing and HLA Genotyping. Matched CSF and plasma samples were analyzed using isoelectric focusing and $\operatorname{IgG}$ specific immunofixation to test the presence of intrathecal specific oligoclonal banding and compared directly with the serum samples (14). Positive oligoclonal banding was defined as more than 2 bands present in the CSF, but absent in the corresponding blood serum (19). The IgG index was calculated from the serum and CSF albumin and $\operatorname{IgG}$ concentrations using the following formula:

IgG index $=($ CSF IgG / serum IgG) $/($ CSF albumin $/$ serum albumin).

The IgG index was considered as high if it was $\geqslant 0.70$ (14).

Blood samples were obtained from patients with MS and stored at $-20^{\circ} \mathrm{C}$. DNA was extracted from blood leukocytes by the standard phenol-chloroform method. DNA was dissolved in the sterile double distilled water. HLA DRB1 alleles for patients with MS were genotyped using the polymerase chain reaction (PCR) with amplification of the second exon of the genes. An amplified product was manually dot blotted onto nylon membranes. Synthetic sequence-specific oligonucleotide probes were $3^{\prime}$-end-labeled with $\alpha$ P32-dCTP and used for hybridization followed by stringency washes and autoradiography. HLA DRB1 alleles were genotyped using the PCR with sequencespecific primers (HLA DRB1*15/16- PCR, PROTRANS Medicinische Diagnostische Produkte GmbH, Germany) and following the manufacture's recommendations. The amplified products were determined by means of agarose gel electrophoresis (20). Laboratory analyses were carried out at the Laboratory of Clinical Chemistry and Genetics, Hospital of Lithuanian University of Health Sciences.

The study was approved by the Kaunas Regional Bioethics Committee. Informed consent form was signed by each patient before the entering the study.

Statistical Analysis. Analysis of the collected data was performed using the statistical package SPSS version 13.0. Clinical variables (disease duration, EDSS score, relapse rate) between groups with or without oligoclonal bands and HLA DRB1*1501 were analyzed with the nonparametric MannWhitney $U$ rank test. Comparisons of mean ages 
at onset across the groups were carried out using the Student $t$ test. Parametric statistics were used for the normally distributed quantitative variables (estimated with the Kolmogorov-Smirnov and Shapiro-Wilk tests); and means with standard deviation (SD) were calculated. The $\chi^{2}$ test was used to compare the qualitative variables and to estimate possible correlations. Odds ratios (OR) with 95\% confidence interval (CI) were calculated to estimate associations. The significance level of $\alpha=0.05$ and $P$ values less than $0.05(P<\alpha)$ were considered as statistically significant.

\section{Results}

Of the 80 patients with MS, two-thirds (67.5\%) had the relapsing-remitting disease course. The mean duration of the symptoms was 10.1 years (SD, 6.74). The male-to-female ratio was 1:1.67. The disease most frequently manifested by visual symptoms $(73.7 \%)$, followed by the brainstem $(47.5 \%)$ and pyramidal symptoms (40.0\%) (Table 1).

Of all the patients, $55 \%$ were positive for OCBs and $56 \%$ for HLA DRB1*1501. Immunogenetic risk factors and main clinical features of patients with MS by presence or absence of OCBs or HLA DRB1*1501 are presented in Table 2 .

The EDSS scores were higher in OCB-positive than OCB-negative MS patients at diagnosis of the disease (3.93 and 3.36, respectively; $P=0.02$ ) and at the last visit (4.31 and 3.09, respectively; $P=0.009$ ). The elevated IgG index was found in $52.5 \%$ of the patients. OCB-positive patients had higher IgG index and mean relapse rate per year than OCB-negative patients $(0.93$ versus $0.53, P=0.001$, and 1.45 versus 0.58 per year, $P=0.001$ ) (Table 2 ).
Table 1. The Main Demographic and Clinical Data of 80 Patients With Multiple Sclerosis

\begin{tabular}{lc}
\hline \multicolumn{1}{c}{ Characteristic } & Value \\
\hline Male-to-female ratio & $1: 1.67$ \\
\hline Age at onset, mean (SD) [range], years & $33.2(8.87)[16-55]$ \\
\hline Disease course: & $54(67.5)$ \\
$\quad$ Relapsing-remitting & $18(22.5)$ \\
$\begin{array}{l}\text { Secondary progressive } \\
\text { Primary progressive }\end{array}$ & $8(10.00)$ \\
\hline Duration of the symptoms, mean (SD), & $10.1(6.74)$ \\
years & $6.66(3.61)$ \\
\hline Duration of the disease (time of diag- & \\
nosis), mean (SD), years & $1.06(0.80)$ \\
\hline Relapse rate per year, mean (SD) & $32(40.0)$ \\
\hline First symptoms: & $30(37.5)$ \\
$\quad$ Pyramidal & $59(73.7)$ \\
Sensory & $13(16.2)$ \\
Visual & $27(33.7)$ \\
Gastrointestinal/bladder & $38(47.5)$ \\
Brainstem & $14(17.5)$ \\
Mental & $3.76(2.10)$ \\
\hline EDSS score during the last visit, mean & \\
(SD) & $3.67(1.13)$ \\
\hline EDSS score at the time of diagnosis, \\
mean (SD)
\end{tabular}

Values are number (percentage) unless otherwise indicated. SD, standard deviation; EDSS, Expanded Disability Status Scale; MRI, magnetic resonance imaging; VEP, visual evoked potential; IgG, immunoglobulin G; OS, oculi sinistri; OD, oculi dextra.

Table 2. Immunogenetic Risk Factors and Main Clinical Features in Patients Multiple Sclerosis by Presence or Absence of Oligoclonal Bands or HLA DRB1*1501

\begin{tabular}{|c|c|c|c|c|c|c|}
\hline Factor & $\begin{array}{l}\text { OCB-positive } \\
\quad \mathrm{N}=44\end{array}$ & $\begin{array}{l}\text { OCB-negative } \\
\mathrm{N}=36\end{array}$ & $P$ & $\begin{array}{c}\text { HLA } \\
\text { DRB1*1501- } \\
\text { positive } \\
\mathrm{N}=45\end{array}$ & $\begin{array}{c}\text { HLA } \\
\text { DRB1*1501- } \\
\text { negative } \\
\mathrm{N}=35\end{array}$ & $P$ \\
\hline Male-to-female ratio & $1: 1.42$ & $1: 2.0$ & 0.5 & $1: 1.25$ & $1: 2.5$ & 0.2 \\
\hline Age at onset, mean (SD), years & $33.1(9.27)$ & $33.5(8.47)$ & 0.19 & $33.4(9.02)$ & $33.1(8.79)$ & 0.42 \\
\hline Relapse rate per year, mean (SD) & $1.45(0.69)$ & $0.58(0.64)$ & 0.001 & $1.15(0.85)$ & $0.94(0.72)$ & 0.34 \\
\hline IgG index & $0.93(0.35)$ & $0.53(0.16)$ & 0.0001 & $0.80(0.36)$ & $0.69(0.31)$ & 0.18 \\
\hline Positive for HLA DRB1*1501 & $27(61.3)$ & $18(50.0)$ & 0.3 & - & - & - \\
\hline $\begin{array}{l}\text { EDSS score at the time of diagnosis, } \\
\text { mean (SD) }\end{array}$ & $3.93(1.21)$ & $3.36(0.96)$ & 0.02 & $3.74(1.12)$ & $3.59(1.15)$ & 0.5 \\
\hline EDSS score at last visit, mean (SD) & $4.31(2.06)$ & $3.09(1.98)$ & 0.009 & $3.94(2.15)$ & $3.54(2.04)$ & 0.4 \\
\hline $\begin{array}{l}\text { Disease course: } \\
\text { RR } \\
\text { SP } \\
\text { PP }\end{array}$ & $\begin{array}{c}26(59.1) \\
12(27.3) \\
6(13.6)\end{array}$ & $\begin{array}{c}28(77.8) \\
6(16.7) \\
2(5.6)\end{array}$ & 0.2 & $\begin{array}{c}29(64.4) \\
12(26.7) \\
4(8.9)\end{array}$ & $\begin{array}{c}25(71.4) \\
6(17.2) \\
4(11.4)\end{array}$ & 0.6 \\
\hline $\begin{array}{l}\text { Relapsing-remitting course } \\
\text { Progressive course }\end{array}$ & $\begin{array}{l}26(59.1) \\
18(40.9)\end{array}$ & $\begin{array}{c}28(77.8) \\
8(22.2)\end{array}$ & 0.076 & $\begin{array}{l}29(64.4) \\
16(35.5)\end{array}$ & $\begin{array}{l}25(71.4) \\
10(28.6)\end{array}$ & 0.5 \\
\hline
\end{tabular}

Values are number (percentage) unless otherwise indicated. OCB, oligoclonal band; RR, relapsing-remitting, SP, secondary progressive, PP, primary progressive, EDSS, Expanded Disability Status Scale. 
Table 3. A Relationship Between the Lesions on Magnetic Resonance Images and the Immunogenetic Factors

\begin{tabular}{|c|c|c|c|c|c|c|}
\hline $\begin{array}{l}\text { Anatomical Location } \\
\text { of Lesions on MRI* }\end{array}$ & $\begin{array}{l}\mathrm{OCB}+ \\
\mathrm{N}=44\end{array}$ & $\begin{array}{l}\mathrm{OCB}- \\
\mathrm{N}=40\end{array}$ & $P$ & $\begin{array}{l}\mathrm{HLA}+ \\
\mathrm{N}=45\end{array}$ & $\begin{array}{l}\text { HLA- } \\
\mathrm{N}=35\end{array}$ & $P$ \\
\hline Periventricular & $40(91.0)$ & $36(90.0)$ & 0.063 & $44(98.0)$ & $32(91.0)$ & 0.2 \\
\hline Corpus callosum & $40(91.0)$ & $34(85.0)$ & 0.5 & $41(91.0)$ & $32(91.0)$ & 0.6 \\
\hline Brainstem & $35(79.5)$ & $18(45.0)$ & 0.005 & $34(75.5)$ & $19(54.0)$ & 0.0046 \\
\hline Cerebellar & $26(59.0)$ & $15(37.5)$ & 0.1 & $26(58.0)$ & $15(43.0)$ & 0.2 \\
\hline Juxtacortical & $25(56.8)$ & $10(25.0)$ & 0.009 & $20(44.0)$ & $15(43.0)$ & 0.9 \\
\hline Spinal cord & $11(25.0)$ & $6(15.0)$ & 0.3 & $10(22.0)$ & $7(20.0)$ & 0.8 \\
\hline
\end{tabular}

Values are number (percentage). *One patient could have more than one lesion.

No association was found between HLA DRB1*1501 antigen status and the clinical features or EDSS score as well as between presence or absence of HLA DRB1*1501 and presence or absence of OCB in the present subset of patients with MS (OR, 1.58; 95\% CI, 0.65 to $3.87 ; P=0.3$ ). Progressive course of the disease tended to be more common than relapsingremitting course in both OCB-positive and HLA DRB1*1501-positive patients with MS, although the difference was not significant (Table 2).

The presence of OCBs was associated with the presence of brainstem lesions and juxtacortical lesions on MRI (OR, 3.89; 95\% CI, 1.45 to 10.37, and OR, 3.42; 95\% CI, 1.33 to 8.77 , respectively). The presence of HLA DRBI*1501 was associated only with brainstem lesions on MRI (OR, 2.60; 95\% CI, 1.00 to 6.73). Table 3 shows the relationship of OCB and HLA DRBI*1501 with lesions on MRI.

\section{Discussion}

In the present study, 55\% of all MS patients were positive for the OCBs and 56\% for the HLA DRB1*1501. OCB-positive MS patients had higher IgG index, mean relapse rate, and EDSS scores than their OCB-negative counterparts. No relationship was found between HLA DRB1*1501 antigen status and the clinical features or EDSS score as well as between presence or absence of HLA DRB1*1501 and presence or absence of OCB in the present subset of MS patients.

The proportion of OCB-positive patients with MS in the present study was much smaller than that in Western European countries, where OCBs are found in $76 \%-90 \%$ of MS patients $(6,21,22)$. It appeared to be much closer to those described in Oriental populations $(55 \%-56 \%)(1,12,23,24)$. These differences might be attributed to immunogenetic factors, which influence the intrathecal immune humoral functions and, at least in part, to different laboratory procedures and techniques $(1,12,21-24)$. Although one of the most sensitive technique to test the presence of intrathecal specific OCB - isoelectric focusing and $\operatorname{Ig} G$ specific immunofixation (19) - was applied in the present study, still such a finding in the Lithuanian population with MS is needed to be confirmed by other studies.
In the present study, the elevated $\operatorname{IgG}$ index was detected in nearly $53 \%$ of patients with MS, and it correlated well with positive OCBs. The IgG index is elevated (>0.6) in about $70 \%-90 \%$ of MS patients, and it is rarely abnormal in OCB-negative patients. The IgG index can be reduced to a reference value with steroid therapy, immunomodulation or immunosuppression, and decreased disease activity (14, $23,25)$. Therefore, it has to be acknowledged that in some cases, CSF analysis was performed in the absence of disease activity.

The presence of OCBs was significantly associated with an increased number of exacerbations as well as with higher disability scores, while no associations between the presence of OCBs and the age at onset, gender, or course of the disease were found in the present study. These findings are consistent with the results presented by Siritho et al. and Koch et al., although in the last-mentioned study, a statement was made that positivity for OCBs indicated a more aggressive course of MS $(14,15)$. This was confirmed by later studies conducted in Italy and Portugal $(26,27)$. On the contrary, Idiman et al. showed that Turkish MS patients who were positive for OCBs had slower disease progression and better disease course with less disability (12).

The presence of OCBs was associated with more frequent lesions juxtacortically and in the brainstem on MRI scans. A study by Huttner et al. showed similar results as in the present study: OCB-positive patients had juxtacortical lesions more frequently $(P=0.022)$, and OCB-negative patients showed a significantly lower prevalence of infratentorial lesions $(P=0.005)(28)$.

In a Caucasian population, HLA DRB1*1501 allele is one of the most important genetic risk factors, associated with the development of MS (1, $11,29)$. Only $56 \%$ of MS patients in the present study were found to have HLA DRB1*1501 allele. The frequency of HLA DRB1*1501 was higher in OCB-positive patients with MS than OCB-negative patients, but the difference was statistically insignificant $(P=0.3)$. Nevertheless, this is in accord with the studies performed in Australia (1), Turkey (12), and Spain (22) where a higher frequency of HLA 
DRB1*1501 allele was reported in OCB-positive patients than OCB-negative patients. No association was found between HLA DRB1*1501 and gender or age at onset. This is in conflict with several other studies reporting that the presence of DR15 was associated with younger age at diagnosis and female sex $(9,11,30,31)$. A relatively small sample of MS patients could be one of the reasons of such a situation. On the other hand, as in the present study, most surveys have found no association between HLA and disease outcome $(11,32,33)$.

Our study has several limitations, which have to be mentioned. First, although it was a prospective study, some clinical data were gathered retrospectively from the medical records. Second, the data presented here were obtained from a relatively small group of MS patients, and this might have influenced partly inconclusive results. Therefore, this study should be judged as a pilot study, and the results have to be confirmed in the larger sample of Lithuanian MS patients.

\section{Conclusions}

The presence of oligoclonal bands in the cerebrospinal fluid of Lithuanian patients with multiple sclerosis was significantly associated with the greater number of exacerbations, higher degree of disability at onset and at the last visit, and higher IgG index. There were no significant associations between the presence of HLA DRB1*1501 allele and the clinical symptoms, course of disease, or disability score. An estimated tendency was observed for those who were positive for HLA DRB1*1501 and also positive for oligoclonal banding proving the hypothesis of the presence of isolated HLA DRB1*1501 haplotype to be insufficient and obligate for the disease development. Moreover, immunogenetic factors are very important for the clinical manifestations, natural course of the disease and, thus, gathering some information on the prognosis and future perspectives.

\section{Statement of Conflict of Interest}

The authors state no conflict of interest.

\title{
Žmogaus leukocitų antigeno DRB1*1501 ir oligokloninių juostų įtaka išsėtinės sklerozès klinikiniam pasireiškimui ir negaliai
}

\author{
Renata Balnyté ${ }^{1}$, Daiva Rastenyte $\dot{e}^{1}$, Ingrida Uloziené⿱2${ }^{2}$, Dalia Mickevičiené $\dot{e}^{1}$, \\ Erika Skrodeniené $\dot{\mathbf{m}}^{3}$, Astra Vitkauskiené $\dot{3}^{3}$ \\ ${ }^{1}$ Lietuvos sveikatos mokslu universiteto Medicinos akademijos Neurologijos klinika, \\ ${ }^{2}$ Lietuvos sveikatos moksly universiteto Medicinos akademijos Ausu, nosies ir gerklès ligu klinika, \\ ${ }^{3}$ Lietuvos sveikatos mokslu universiteto Medicinos akademijos Laboratorinès medicinos klinika
}

Raktažodžiai: išsėtinè sklerozè, žmogaus leukocitų antigenas DRB1*1501, oligokloninės juostos, klinikiniai požymiai, negalia.

Santrauka. Tyrimo tikslas. İvardyti imunogenetinių rizikos veiksnių reikšmę, jų galimą įtaką klinikiniam išsètinès sklerozès pasireiškimui ir negalios atsiradimui sergantiesiems išsètine skleroze Lietuvos populiacijoje.

Tyrimo medžiaga ir metodai. Atliktas perspektyvusis tyrimas su 80 sergančiųiu išsètine skleroze. Diagnozė patvirtinta McDonaldo kriterijais. Oligokloninès juostos nustatytos naudojant izoelektrinio fokusavimo ir IgG imunofiksacijos metodą. HLA aleliai sergantiesiems išsètine skleroze buvo nustatyti naudojant polimerazès grandininę reakciją.

Rezultatai. 55 proc. tiriamųjų rasta oligokloninių juostų, 56 proc. rastas HLA DRB1*1501 alelis. Sergantieji išsètine skleroze, kuriems rasta oligokloninių juostų, turèjo didesnę negalią pagal EDSS ligos pradžioje, lyginant su tiriamaisiais, kuriems oligokloninių juostų nerasta $(3,93 \pm 1,21$ ir $3,36 \pm 0,96$ balo, $p=0,02)$ ir paskutinio vizito metu $(4,31 \pm 2,06$ ir $3,09 \pm 1,98$ balo, $\mathrm{p}=0,009)$. Paūméjimų dažnis buvo didesnis tiriamiesiems, kuriems rasta oligokloninių juostų, lyginant su grupe tiriamųjų, kuriems oligokloninių juostų nerasta $(1,45 \pm 0,69$ ir $0,58 \pm 0,64, \mathrm{p}=0,001)$. Tiriamieji, kuriems rasta oligokloninių juostų, turejo didesni IgG indeksą lyginant su tiriamaisiais, kuriems oligokloninių juostų nerasta $(\mathrm{p}=0,0001)$. Nerasta ryšio tarp HLA DRB1*1501 ir klinikinių požymių, EDSS bei oligokloninių juostų turinčiais ir neturinčiais pacientais.

Išvados. Oligokloninės juostos, rastos sergančiuju išsėtine skleroze smegenu skystyje, turèjo ryši su didesniu paūmèjimų skaičiumi, didesne negalia ir didesniu IgG indeksu. HLA DRB1*1501 allelis nekoreliavo nei su klinikiniais simptomais, nei su ligos eiga ir negalia. 


\section{References}

1. Wu JS, Qui W, Castley A, James I, Joseph J, Christiansen FT, et al. Presence of CSF oligoclonal bands is associated with the HLA-DRB1 genotype in a West Australian multiple sclerosis cohort. I Neurol Sci 2010;288:63-7.

2. Bennett JL. Multiple sclerosis pathophysiology update. Adv Stud Pharm 2009;3:58-62.

3. Milo R, Kahana E. Multiple sclerosis: geoepidemiology, genetics and the environment. Autoimmun Rev 2010;9:A38794.

4. Pirko I, Noseworthy JH. Demyelinating disorders of the central nervous system. In: Goetz CG, editor. Textbook of clinical neurology. 3rd ed. Philadelphia, PA: Saunders Elsevier; 2007. p. 1103-35.

5. Schmidt H, Williamson D, Ashley-Koch A. HLA-DR15 haplotype and multiple sclerosis: a HuGe review. Am J Epidemiol 2007;165:1097-109.

6. Imrell K, Greiner E, Hillert I, Mastermann T. HLADRB1*15 and cerebrospinal-fluid-specific oligoclonal immunoglobulin $\mathrm{G}$ bands lower age at attainment of important disease milestones in multiple sclerosis. I Neuroimmunol 2009;210:128-30.

7. DeLuca GC, Ramagopalan SV, Herrera BM, Dyment DA, Lincoln MR, Montpetit A, et al. An extremes of outcome strategy provides evidence that multiple sclerosis severity is determined by alleles at the HLA-DRB1 locus. Proc Natl Acad Sci U S A 2007;52:20896-901.

8. Okuda DT, Srinivasan R, Oksenberg JR, Goodin DS, Baranzini SE, Beheshtian A, et al. Genotype-phenotype correlations in multiple sclerosis: HLA genes influence disease severity inferred by HMR spectroscopy and MRI measures. Brain 2009;132:250-9.

9. Masterman T, Ligers A, Olsson T, Andersson M, Olerup O, Hillert J. HLA-DR 15 is associated with lower age at onset in multiple sclerosis. Ann Neurol 2000;48:211-9.

10. Weatherby SI, Thomson W, Pepper L, Donn R, Worthington J, Mann CL, et al. HLA DRB1 and disease outcome in multiple sclerosis. J Neurol 2001;248:304-10.

11. Hensiek AE, Sawcer SJ, Feakes R, Deans J, Mander A, Akesson E, et al. HLA-DR15 is associated with female sex and younger age at diagnosis in multiple sclerosis. J Neurol Neurosurg Psychiatry 2002;72:184-7.

12. Idiman E, Ozakbas S, Dogan Y, Kosehasanogullari G. The significance of oligoclonal bands in multiple sclerosis: relevance of demographic and clinical features, and immunogenetic backgrounds. J Neuroimmunol 2009;212:121-4.

13. Villar LM, Masterman T, Casanova B, Gomez-Rial J, Espino M, Sadaba MC, et al. CSF oligoclonal band patterns reveal disease heterogeneity in multiple sclerosis. J Neuroimmunol 2009;211:101-4

14. Siritho S, Freedman MS. The prognostic significance of cerebrospinal fluid in multiple sclerosis. J Neurol Sci 2009; 279:21-5.

15. Koch M, Heersema D, Mostert I, Teelken A, De Keyser J. Cerebrospinal fluid oligoclonal bands and progression of disability in multiple sclerosis. Eur J Neurol 2007;14:797800.

16. World Health Organization, Multiple Sclerosis International Federation. Atlas multiple sclerosis resources in the world 2008. Geneva: World Health Organization; 2008. Available from: URL: www.who.int/entity/mental health/neurology/ Atlas MS WEB.pdf

17. Polman CH, Reingold SC, Edan G. Diagnostic criteria for multiple sclerosis: 2005 revisions to the McDonald criteria. Ann Neurol 2005;6:840-6.
18. Celesia GG, Brigell MG. Recommended standards for pattern electroretinograms and visual evoked potentials. In: Deuschl G, Eisen A, editors. Recommendations for the practice of clinical neurophysiology: guidelines of the International Federation of Clinical Physiology (EEG, suppl 52). Elsevier Science; 1999.

19. Freedman MS, Thompson EJ, Deisenhammer F, Giovannoni G, Grimsley G, Keir G, et al. Recommended standard of cerebrospinal fluid analysis in the diagnosis of multiple sclerosis. Arch Neurol 2005;62:865-70.

20. Skrodenienė E, Marčiulionytė D, Padaiga Ž, Jašinskienė, Sadauskaitė-Kuehne V, Sanjeevi CB, et al. HLA class II alleles and haplotypes in Lithuanian children with type I diabetes and healthy children (HLA and type I diabetes). Medicina (Kaunas) 2010;8:505-10.

21. Link H, Huang YM. Oligoclonal bands in multiple sclerosis cerebrospinal fluid: an update on methodology and clinical usefulness. J Neuroimmunol 2006;180:17-28.

22. Romero-Pinel L, Yelamos-Martinez S, Bau L, Matas E, Guberias L, Maria Pujai J, et al. Association of HLA DRB1*15 allele and CSF oligoclonal bands in a Spanish multiple sclerosis cohort. Eur J Neurol 2011;18(10):1258-62.

23. Nakashima I, Fujihara K, Misu T, Fujimori J, Sato S, Takase $\mathrm{S}$, et al. Comparative study of Japanese multiple sclerosis patients with and without oligoclonal IgG bands. Mult Scler 2002;8:459-62.

24. Diniz da Gama P, Machado LR, Livramento JA, Gomes HR, Adoni T, Martins Lino AM, et al. Study of oligoclonal bands restricted to the cerebrospinal fluid in multiple sclerosis patients in the city of Sao Paulo. Arq Neuropsiquiatr 2009;4:1017-22.

25. Awad A, Hemmer B, Hartung PH, Kieseier B, Bennett JL, Stuve O. Analysis of cerebrospinal fluid in the diagnosis and monitoring of multiple sclerosis. J Neuroimmunol 2010; 219:1-7.

26. Sa MJ, Sequera L, Rio ME, Thompson EJ. Oligoclonal IgG bands in the CSF of Portuguese patients with MS. Arq Neuropsiquiatr 2005;63:375-9.

27. Amato MP, Ponziani G. A prospective study on the prognosis of multiple sclerosis. J Neurol Sci 2000;21:S831-8.

28. Huttner HB, Schellinger PD, Struffert T, Ricter G, Engelhorn T, Bassemir T, et al. MRI criteria in MS patients with negative and positive oligoclonal bands: equal fulfillment of Barkhof's criteria but different lesion patterns. J Neurol 2009;256:1121-5.

29. Oksenberg JR, Baranzini SE. Multiple sclerosis genetics: is the glass half empty or half full? Nat Rev Neurol 2010; 6:429-37.

30. Celius EG, Harbo HF, Egeland T, Vartdal F, Vandvik K, Spurkiand A. Sex and age at diagnosis are correlated with HLA-DR2, DQ6 haplotype in multiple sclerosis. I Neurol Sci 2000;178:132-5

31. Smestad C, Brynedal B, Jonasdottir G, Lorentzen AR, Masterman T, Akesson E, et al. The impact of the HLA-A and -DRB1 on age at onset, disease course and severity in Scandinavian multiple sclerosis patients. Eur J Neurol 2007; 14:835-40.

32. McDonell GV, Mawhinney H, Graham CA, Hawkins SA, Middleton D. A study of the HLA-DR region in clinical subgroups of multiple sclerosis and its influence on prognosis. J Neurol Sci 1999;165:77-83.

33. Weinsheker BG, Santrach P, Bissonet AS, McDonell SK, Shaid D, Moore SB, et al. Major histocompatibility complex class II alleles and the course and outcome of MS: a population-based study. Neurology 1998;51:742-7. 